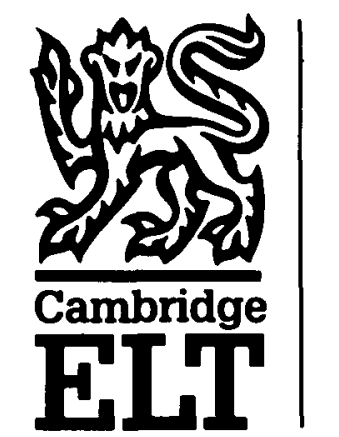

\title{
Teach English
}

\section{A training course for teachers}

\section{Adrian Doff}

Ii. Teaching large classes in inflexible classrooms with few resources?

Following a set syllabus and textbook, with little control over course content or choice of material?

Dittle time for lesson planning or preparation?

Teach English is the teacher training course which addresses the problems of teachers in these situations and develops practical skills in teaching English as a foreign language.

Developed from a set of materials produced as part of a highly successfu] British Council project, and especially designed to meet the needs of teachers whose first language is not English, Teach English can be used:

In in-service courses for teachers working at secondary level in schools or language institutes
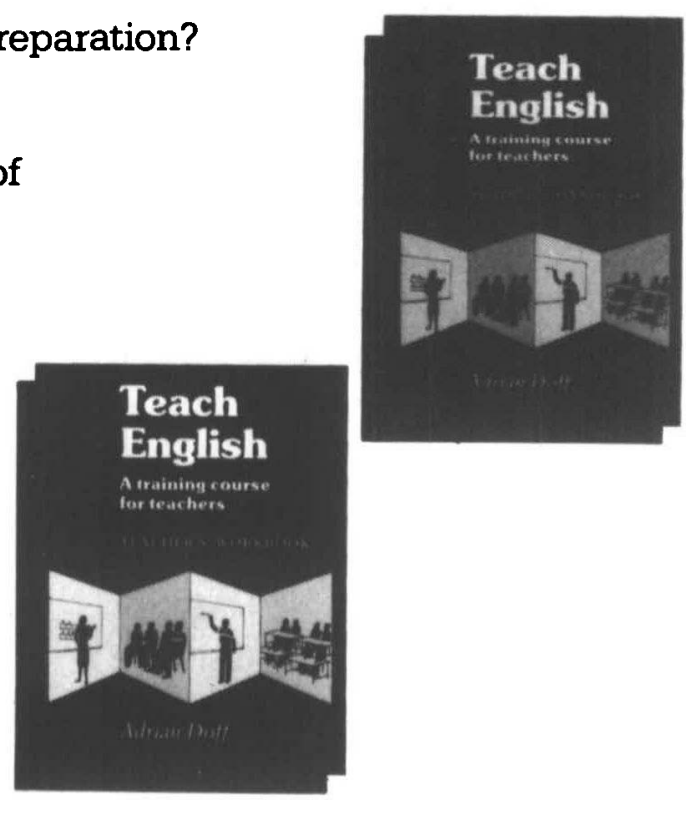

- in pre-service training of secondary school teachers, as a practical component of a methodology course and as preparation for teaching practice

- as part of a 'refresher course' in practical methodology for more experienced teachers.

The course is designed to be used actively by a trainer working with a group of up to 30 teachers. The Trainer's Handbook incorporates the Teacher's Workbook and contains detailed guidance on how the materials can be used.

\section{3 0521348641}

Teacher's Workbook Trainer's Handbook

For further information on all Cambridge ELT publications, please contact

Claire Stanfield, ELT Publicity Controller,

Cambridge University Press,

The Edinburgh Building, Shaftesbury

Road, Cambridge CB2 2RU, UK. 


\section{Cambridge Applied Linguistics}

Series Editors: Professor Michael H. Long and Professor Jack C. Richards

This new series presents the latest insights from theory and research, and will enable applied linguists, teachers and researchers to keep up to date in this rapidly developing field. The first books in the series are:

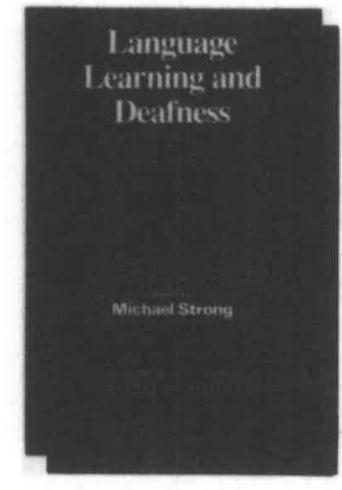

\section{Language Learning and Deafness}

Edited by Michael Strong

The study of language learning by the deaf can yield important insights into language learning and acquisition by hearing populations as well as being a vital field of enquiry in its own right.

\section{Second Language Classrooms}

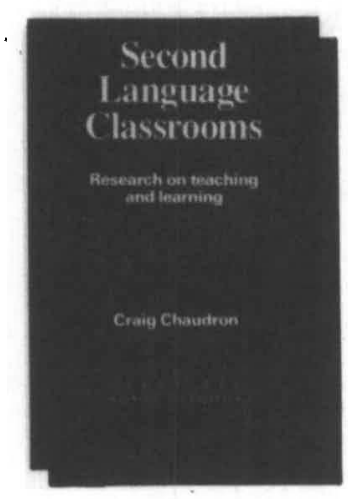

Research on teaching and learning

\section{Craig Chaudron}

This book provides a critical survey of recent classroomcentred research and its implications for the teaching and learning of languages. The aim is to identify those characteristics of classroom instruction that lead to the most efficient learning, so that effective language courses and teacher training programmes can be implemented.

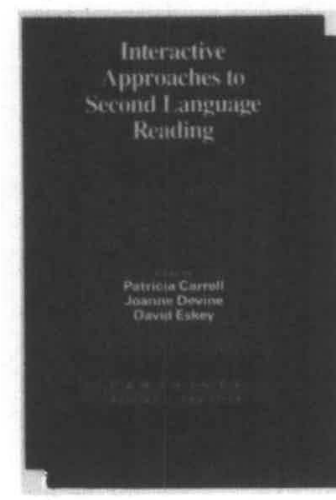

\section{Interactive Approaches to \\ Second Language Reading}

Edited by Patricia L. Carrell, Joanne Devine and David E. Eskey Reading is increasingly being seen as a process of interaction between the reader and the text. This authoritative collection presents up-to-date models, theory, research, and classroom applications in second language reading from this perspective.

The editors provide a clear introduction to the field and guide the reader through the contributions.

All three books are available in hard covers or paperback.

For further information on all Cambridge ELT publications, please contact Claire Stanfield, ELT Publicity Controller,

Cambridge University Press,

The Edinburgh Building, Shaftesbury

Road, Cambridge CB2 2RU, UK.

CAMBRIDGE UNIVERSITY PRESS 


\section{language teaching}

The international abstracting journal

for language teachers and applied linguists

October 1988 Volume 21 no 4

\section{Contents}

Abstracts Language learning and teaching -

385-469 theory and practice

$470-490$

Teaching particular languages

$491-518$

Research in the supporting sciences

$519-522$

Language description and use

New books

Bibliographies

\section{$\because \because \%$

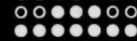

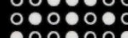 \\ The British Council \\ CIIT}

Cambridge University Press 